\title{
PERBANDINGAN KEMAMPUAN BERPIKIR KRITIS MENGGUNAKAN MODEL PEMBELAJARAN CONTEXTUAL TEACHING AND LEARNING (CTL) DENGAN MODEL PEMBELAJARAN LANGSUNG SISWA KELAS VIII SMP NEGERI 5 KOTA JAMBI
}

\author{
Siti Mahmudah ${ }^{1}, \operatorname{Harman}^{2}$, Sri Dewi ${ }^{3}$ \\ Program Studi Pendidikan Matematika, FKIP, Universitas Batanghari ${ }^{1,2,3}$ \\ Jl. Slamet Riyadi No.1 Broni Jambi \\ e-mail: -
}

\begin{abstract}
ABSTRAK
Kemampuan berpikir kritis adalah bentuk kemampuan berpikir yang perlu dikembangkan untuk menyelesaikan masalah, merumuskan kesimpulan, mengumpulkan kemungkinan, dan membuat keputusan saat menggunakan semua keterampilan itu secara efektif dalam konteks dan jenis yang tepat. Kemampuan untuk berpikir kritis dapat mendorong siswa untuk menghasilkan ide atau pemikiran baru tentang suatu masalah. Mengembangkan keterampilan berpikir kritis siswa dapat membantu siswa membuat kesimpulan dengan mempertimbangkan data dan fakta yang terjadi di lapangan. Penelitian ini merupakan penelitian eksperimental dengan desain penelitian menggunakan desain eksperimen Posttest Only Control Design. Populasi dalam penelitian ini adalah semua siswa kelas VIII SMPN 5 Kota Jambi yang terdiri dari sebelas kelas. Sedangkan sampelnya adalah siswa kelas VIII C sebagai kelas eksperimen dan kelas VIII J sebagai kelas kontrol yang diambil secara random sampling. Dari hasil analisis data yang dilakukan pada dua sampel diperoleh nilai rata-rata kemampuan berpikir kritis kelas eksperimen 71,36 dengan standar deviasi 16,17 dan nilai rata-rata keterampilan berpikir kritis kelas 63,82 dengan standar deviasi 15,58, dan hasil uji hipotesis diperoleh thitung 2,067 dan ttabel 1,67 pada taraf nyata $\alpha$ adalah 0,05. Dari hasil perhitungan dapat diketahui bahwa thitung lebih dari ttabel, sehingga H0 ditolak dan $\mathrm{H} 1$ diterima. Berdasarkan hasil akhir, dapat disimpulkan bahwa ada perbandingan kemampuan berpikir kritis siswa yang diajarkan dengan menggunakan model Contextual Teaching and Learning lebih tinggi daripada kemampuan berpikir kritis siswa yang diajarkan dengan menggunakan model pembelajaran langsung.
\end{abstract}

\section{Kata kunci:}

Keterampilan Berpikir Kritis, Model Pembelajaran Kontekstual, dan Model Langsung

\begin{abstract}
The ability to think critically is a form of thinking ability that needs to be developed in order to solve problems, formulate conclusions, collect possibilities, and make decisions when using all those skills effectively in the right context and type. The ability to think critically can encourage students to come up with new ideas or thoughts about a problem. Developing students' critical thinking skills can help students make conclusions by considering data and facts that occur in the field. This research is an experimental research with research design using experimental design Posttest Only Control Design. The population in this study is all students of class VIII SMPN 5 Kota Jambi consisting of eleven classes. While the sample is the students of class VIII C as the experimental class and class VIII $J$ as the control class taken by random sampling. From the result of data analysis conducted on two samples obtained the average value of critical thinking ability of experimental class 71,36 with standard deviation 16,17 and mean value of critical thinking skill of class of 63,82 with standard deviation 15,58, and result hypothesis test obtained $t_{\text {count }} 2.067$ and $t_{\text {table }} 1.67$ at the level of real $\alpha$ is 0,05 . From the calculation result it can be seen that $t_{\text {count }}$ is more than $t_{\text {table, }}$ so $H_{0}$ is rejected and $H_{1}$ accepted. Based on the final result, it can be concluded that there is a comparison of students' critical thinking ability taught by using Contextual Teaching and Learning model is higher than the critical thinking ability of students taught by using direct learning model.
\end{abstract}

Keywords:

Critical Thinking Skills, Contextual Teaching and Learning Model, and Direct Learning Model 


\section{PENDAHULUAN}

Tujuan pembelajaran pendidikan nasional adalah mengembangkan potensi siswa agar menjadi manusia yang beriman dan bertakwa kepada Tuhan Yang Maha Esa, berakhlak mulia, sehat, berilmu, mandiri, demokratis serta memiliki rasa tanggungjawab. Sebagai upaya meningkatkan mutu pendidikan, fungsi sekolah sangatlah penting melalui proses pembelajaran. Dalam proses pembelajaran di sekolah memuat berbagai mata pelajaran, salah satunya adalah mata pelajaran matematika.

Matematika adalah bagian dari mata pelajaran di sekolah yang berfungsi sebagai alat untuk memahami dan menyampaikan suatu informasi. Selain itu, juga sebagai pembentukan pola pikir dalam pemahaman suatu pengertian maupun dalam penalaran suatu hubungan diantara pengertian-pengertian itu, serta berfungsi sebagai ilmu atau pengetahuan. Untuk mewujudkan tujuan pendidikan salah satunya yaitu menumbuhkan kemampuan individu. Salah satu kemampuan dalam pendidikan matematika adalah kemampuan berpikir kritis.

Kemampuan berpikir kritis merupakan salah satu kemampuan yang dapat dikembangkan dalam diri setiap peserta didik. Setiap peserta didik memiliki kemampuan berpikir kritis masing-masing. Kemampuan berpikir kritis sangat penting peranannya bagi siswa dan harus ditanamkan sejak dini baik di sekolah, dirumah maupun di lingkungan masyarakat. Siswa dikatakan memiliki kemampuan berpikir kritis jika mampu menganalisis dan mengidentifikasi masalah, mensintesis, mengenal dan memecahkan masalah, menyimpulkan dan mengevaluasi. Menurut Ennis (Susanto, 2013) kemampuan berpikir kritis adalah kemampuan berpikir menggunakan logika untuk mendapatkan pengetahuan yang disertai pengkajian kebenaran berdasarkan pola penalaran tertentu.

Kemampuan berpikir kritis dapat juga dikatakan sebagai suatu keterampilan berpikir secara reflektif untuk memutuskan hal-hal yang dilakukan. Kemampuan berpikir kritis dibutuhkan untuk melatih siswa menyelesaikan permasalahan yang tidak hanya berhubungan dengan pembelajaran di sekolah, namun juga permasalahan dalam kehidupan nyata. Oleh karena itu, kemampuan berpikir kritis dalam proses pembelajaran perlu dilatih dan dikembangkan oleh guru. Untuk mengembangkan kemampuan berpikir kritis siswa memerlukan keahlian guru dalam mengelola proses belajar di kelas. Guru harus dapat mengembangkan suasana kelas agar siswa berpartisipasi selama proses belajar berlangsung. Guru juga dapat menerapkan bentuk latihanlatihan yang mengacu pada pola pikir siswa seperti memberikan latihan berbentuk soal cerita.

Kemampuan berpikir kritis perlu dikembangkan agar siswa dapat lebih mudah memahami konsep, peka akan masalah yang terjadi sehingga dapat memahami dan menyelesaikan masalah, dan mampu mengaplikasikan konsep dalam situasi yang berbeda. Akan tetapi kenyataannya, siswa mengalami kesulitan dalam menyelesaikan soal yang diberikan guru. Kebanyakan siswa menyelesaikan soal tanpa pemahaman yang mendalam. Saat menyelesaikan soal siswa hanya berorientasi pada jawaban akhir tanpa memfokuskan pertanyaan dan menggunakan penalarannya. Selain itu, siswa juga kurang mampu membuat kesimpulan serta tidak menggunakan strategi dalam menyelesaikan soal. Hal ini menunjukkan masih rendahnya kemampuan berpikir kritis siswa. Mengingat pentingnya kemampuan 


\section{$\pi$ (Phi)}

berpikir kritis dalam proses pembelajaran matematika maka setiap siswa dituntut memiliki kemampuan berpikir kritis. Namun kenyataan dilapangan kemampuan berpikir kritis siswa masih rendah.

Salah satu faktor lain yang mempengaruhi perkembangan kemampuan berpikir siswa adalah suasana kelas yang interaktif. Agar pembelajaran dapat interaktif maka perlu desain pembelajaran yang menarik sehingga siswa dapat telibat aktif dalam proses pembelajaran. Saat di lapangan, proses pembelajaran yang dilaksanakan oleh guru di dalam kelas menggunakan model pembelajaran langsung. Model pembelajaran langsung merupakan model pembelajaran yang digunakan guru dimana dalam proses pembelajaran guru lebih aktif dari pada siswa. Sehingga membuat siswa kurang berpartisipasi dan proses pembelajaran menjadi monoton. Penggunaan model pembelajaran yang kurang tepat merupakan salah satu faktor yang mempengaruhi kemampuan berpikir kritis siswa. Mengingat kemampuan berpikir kritis setiap siswa berbeda-beda maka guru perlu melatih dan meningkatkan kemampuan berpikir kritis siswa.

Salah satu upaya untuk meningkatkan kemampuan berpikir kritis siswa adalah dengan menggunakan model pembelajaran yang inovatif. Model pembelajaran inovatif yang dapat digunakan adalah model pembelajaran Contextual Teaching and Learning. Model pembelajaran Contextual Teaching and Learning adalah model pembelajaran yang membantu guru mengaitkan antara materi yang diajarkan dengan situasi dunia nyata. Model ini mendorong siswa membuat hubungan antara pengetahuan yang dimilikinya dengan penerapannya dalam kehidupan sehari-hari.

Model pembelajaran Contextual Teaching and Learning juga dipandang sebagai suatu model pembelajaran yang memungkinkan siswa untuk menerapkan pemahaman dan kemampuan akademiknya dalam berbagai variasi konteks. Model pembelajaran Contextual Teaching and Learning menekankan kepada siswa pentingnya membangun sendiri pengetahuan mereka serta mengkonstruksi sendiri pengetahuan dan keterampilan barunya melalui keterlibatan aktif dalam proses belajar mengajar. Model Contextual Teaching and Learning juga menekankan pada level berpikir tingkat tinggi. Model pembelajaran ini melatih siswa untuk berpikir kritis dalam mengumpulkan data, memahami suatu isu, atau memecahkan suatu masalah. Proses ini dapat dilakukan pada kegiatan inquiry dimana dalam kegiatan tersebut terjadi proses perpindahan dari pengamatan menjadi pemahaman. Oleh karena itu, melalui model pembelajaran ini diharapkan dapat meningkatkan kemampuan berpikir kritis siswa.

\section{METODE PENELITIAN}

Jenis penelitian ini merupakan penelitian eksperimen, menurut Sugiyono (2013) metode penelitian eksperimen dapat diartikan sebagai metode penelitian yang digunakan untuk mencari pengaruh perlakuan tertentu terhadap yang lain dalam kondisi yang terkendalikan. Adapun menurut Arikunto (2010) penelitian eksperimen dikenal dengan penelitian percobaan. Penelitian eksperimen mencobakan perlakuan (treatment) dimaksudkan untuk mengetahui akibat atau dampak sesuatu kejadian atau variabel yang dihadirkan oleh peneliti.

Penelitian eksperimen ini dilakukan pada dua kelas, yaitu kelas eksperimen dan kelas kontrol. Kelas eksperimen adalah kelas yang diajarkan dengan menggunakan model pembelajaran Contextual Teaching and Learning 


\section{$\pi$ (Phi)}

sedangkan kelas kontrol menggunakan model pembelajaran langsung.

Populasi adalah keseluruhan subjek penelitian. Menurut Sugiyono (2013) populasi adalah wilayah generalisasi yang terdiri atas:objek atau subjek yang mempunyai kualitas dan karakteristik tertentu yang diterapkan oleh peneliti untuk dipelajari dan kemudian ditarik kesimpulannya. Jadi, populasi adalah objek atau subjek yang berada pada suatu wilayah dan memenuhi syarat-syarat tertentu berkaitan dengan masalah atau objek penelitian. Populasi pada penelitian ini adalah seluruh siswa kelas VIII SMP Negeri 5 Kota Jambi, yang terbagi pada 11 kelas.

Pengambilan sampel dalam penelitian ini menggunakan teknik random sampling, yaitu teknik pengambilan anggota sampel dari populasi dilakukan secara acak tanpa memperhatikan strata yang ada dalam populasi. Sedangkan untuk menentukan kelas ekperimen dan kelas kontrol digunakan teknik undian. Yang terpilih pertama yaitu kelas VIII C dijadikan sebagai kelas eksperimen dan yang terpilih kedua adalah kelas VIII J sebagai kelas kontrol. Kelas eksperimen adalah kelas yang diajar dengan model pembelajaran Contextual Teaching and Learning sedangkan kelas kontrol adalah kelas yang diajar dengan model pembelajaran langsung.

Menurut Sugiyono (2013) alat ukur dalam penelitian biasanya dinamakan instrumen penelitian. Jadi instrumen penelitian adalah suatu alat yang digunakan mengukur fenomena alam maupun sosial yang diamati. Instrumen dalam penelitian ini digunakan untuk memperoleh data berupa tes kemampuan berpikir kritis siswa. Instrumen yang digunakan dalam penelitian ini adalah tes uraian yang memenuhi kriteria validitas, tingkat kesukaran, daya pembeda, dan reabilitas. Tes akhir (post-test) dilakukan setelah berakhirnya rangkaian pembelajaran pada kelas sampel.

Teknik pengumpulan data merupakan langkah yang paling strategis dalam penelitian, karena tujuan utama dari penelitian adalah mendapatkan data. Adapun langkah-langkah yang dilakukan untuk mendapatkan data penelitian adalah sebagai berikut:

1. Tahap Persiapan

Pada tahap ini peneliti menyiapkan segala hal yang berhubungan dengan pelaksanaan penelitian. Hal yang pertama peneliti lakukan adalah menentukan kelas sampel yang akan diteliti yaitu kelas eksperimen dan kelas kontrol. Setelah kelas sampel didapat peneliti mulai membuat instrumen penelitian. Peneliti mulai mencari informasi tentang alokasi waktu pengajaran sehingga peneliti dapat menyusun jadwal kegiatan penelitian. Menyusun rencana pengajaran yang berpedoman pada kurikulum mata pelajaran matematika SMP Negeri 5 Kota Jambi yang dipakai. Peneliti juga mempersiapkan pengajaran dengan model Contextual Teachingand Learning pada kelas eksperimen serta pengajaran dengan model pembelajaran langsung pada kelas kontrol.

2. Tahap Pelaksanaan

Dalam tahap pelaksanaan pembelajaran peneliti menerapkan model pembelajaran Contextual Teaching and Learning pada kelas eksperimen dan model pembelajaran langsung pada kelas kontrol sesuai dengan langkahlangkah pembelajaran.

3. Tahap Akhir

Dalam tahap akhir yang dilakukan peneliti yaitu mempersiapkan post-test, memberikan post-test pada sampel diakhir pokok bahasan dan menganalisis skor rata-rata hasil post- 


\section{$\pi$ (Phi)}

test serta mengambil kesimpulan.

Data yang dianalisis adalah skor hasil tes akhir siswa kelompok kelas eksperimen dan kelompok kelas kontrol. Setelah data diperoleh dilakukan analisis data untuk menguji hipotesis dengan membandingkan skor rata-rata nilai siswa kelompok kelas eksperimen dan kelompok kelas kontrol. Metode statistik yang digunakan adalah uji hipotesis dengan uji Anava satu arah. Sebelum dianalisis dilakukan terlebih dahulu uji normalitas dan uji homogenitas.

\section{HASIL DAN PEMBAHASAN}

Jumlah siswa pada kelas eksperimen adalah 36 siswa dan kelas kontrol sebanyak 39 siswa. Rata-rata nilai kemampuan berpikir kritis siswa dikelas eksperimen adalah 71,36 dengan nilai tertinggi 95 dan nilai terendah 30. Simpangan baku kelas eksperimen adalah 16,17 sehingga varians sebesar 261,4944. Sedangkan rata-rata nilai kemampuan berpikir kritis siswa dikelas kontrol adalah 63,82 dengan nilai tertinggi 90 dan nilai terendah 30. Simpangan baku kelas eksperimen adalah 15,58 sehingga varians sebesar 242,7301. Sehingga dapat disimpulkan bahwa rata-rata kemampuan berpikir kritis siswa yang diajarkan dengan menggunakan model pembelajaran Contextual Teaching and Learning lebih tinggi dari pada rata-rata kemampuan berpikir kritis siswa yang diajarkan dengan menggunakan model pembelajaran langsung.

Dapat dilihat bahwa nilai tertinggi dan terendah pada kelas eksperimen dan kelas kontrol memberikan dampak yang berbanding lurus terhadap hasil perhitungan rata-rata dan simpangan baku. Dapat dilihat nilai rata-rata dan simpangan baku kelas eksperimen lebih tinggi dibandingkan dengan kelas kontrol. Sehingga dapat disimpulkan bahwa dalam proses pembelajaran penggunaan model pembelajaran Contextual Teaching and Learning memperoleh rata- rata kemampuan berpikir kritis siswa yang lebih tinggi dibandingkan dengan pembelajaran yang menggunakan model pembelajaran langsung.

Pengujian prasyarat dilakukan sebelum pengujian hipotesis. Data yang akan dianalisis merupakan data tes kemampuan berpikir kritis siswa yang melalui pembelajaran dengan model pembelajaran Contextual Teaching and Learning. Uji prasyarat yang dilakukan adalah uji normalitas dan uji homogenitas.

Uji hipotesis bertujuan untuk mengetahui apakah ada perbandingan kemampuan berpikir kritis siswa yang diajarkan menggunakan model pembelajaran Contextual Teaching and Learning dengan kemampuan berpikir kritis siswa yang diajarkan dengan model pembelajaran langsung. Hipotesis yang akan diuji adalah:

$H_{0}=\mu_{1} \leq \mu_{2}$

$H_{1}=\mu_{2}>\mu_{1}$

Dari perhitungan diperoleh nilai thit sebesar 2,067 dan $t_{\text {tabel }}$ sebesar 1,67.

Kriteria pengujian:

Jika $t_{\text {hit }}$ lebih kecil dari pada $\mathrm{t}_{\text {tab }}$ maka $\mathrm{H}_{0}$ ditolak. Karena nilai $t_{\text {hit }}$ lebih kecil dari pada tab maka $\mathrm{H}_{0}$ ditolak dan $\mathrm{H}_{1}$ diterima. Jadi, dapat disimpulkan bahwa rata-rata kemampuan berpikir kritis siswa yang diajarkan menggunakan model pembelajaran Contextual Teaching and Learning lebih tinggi dari pada yang dibelajarkan dengan menggunakan model pembelajaran langsung.

Pelaksanaan pada kelas eksperimen diberikan perlakuan model pembelajaran Contextual Teaching and Learning dan kelas kontrol tetap pada keadaan biasanya yaitu dengan model pembelajaran 


\section{$\pi$ (Phi)}

langsung. Dengan adanya perbedaan dalam proses pembelajaran penulis mengharapkan dapat melihat perbandingan pada kemampuan berpikir kritis siswa di kelas VIII SMP Negeri 5 Kota Jambi.

Pada proses pelaksanaan di kelas eksperimen, menggunakan model pembelajaran Contextual Teaching and Learning kepada siswa dalam melakukan pembelajaran materi persamaan garis lurus. Siswa dituntut aktif dalam memahami materi. Siswa di kelas eksperimen ini mempelajari materi disertai dengan kegiatan praktek. Pada pertemuan pertama siswa diberikan soal untuk diamati dan melatih siswa untuk menemukan sendiri penyelesaian mengenai grafik persamaan garis lurus. Siswa dalam kelompok dibimbing untuk dapat memahami pembelajaran dengan adanya kegiatan pengamatan. Padát pertemuan kedua siswa diminta untuk menemukan cara menentukan kemiringan (gradien) persamaan garis lurus berdasarkan gambar yang disediakan. Begitu seterusnya sampai pertemuan keenam.

Selama proses pembelajaran di kelas eksperimen berlangsung siswa terlihat aktif dan memiliki rasa ingin tahu yang tinggi terhadap materi yang disampaikan. Siswa diikutsertakan dalam kegiatan praktek seperti menggambar dan sebagainya. Sehingga suasana kelas tidak kaku, proses pembelajaran lebih asik dan kreatif. Selanjutnya, kemampuan berpikir kritis siswa di kelas eksperimen terbukti lebih tinggi. Hal ini dapat dilihat pada pelaksanaan post-test. Siswa kelas eksperimen mampu mengerjakan soal dengan benar dan tepat. Sehingga nilai rata-rata dari keseluruhan siswa di kelas eksperimen memperoleh angka yang memuaskan.

Berbeda dengan kelas eksperimen, kelas kontrol diajarkan dengan model pembelajaran langsung. Selama proses pembelajaran siswa diajarkan dengan metode ceramah. Dengan bantuan buku paket yang diberikan kepada siswa, siswa memahami lalu mengerjakan soal- soal dalam buku tersebut. Proses pembelajaran dalam kelas kontrol lebih monoton dengan pemberian materi hanya satu arah. Sedikit sekali siswa yang memiliki minat untuk memberikan umpan balik atas materi yang disampaikan. Dengan demikian guru kembali menerangkan materi yang sama. Sehingga proses pembelajaran yang diajarkan di kelas kontrol kurang efektif dan efisien.

\section{SIMPULAN DAN SARAN}

Berdasarkan hasil post-test pada bahasan persamaan garis lurus, kemampuan berpikir kritis siswa kelas eksperimen yang diajarkan dengan menggunakan model pembelajaran Contextual Teaching and Learning memperoleh nilai rata-rata 71,36 dengan simpangan baku 16,17. Sedangkan kelas kontrol yang diajarkan dengan model pembelajaran langsung memperoleh ratarata 63,82 dengan simpangan baku 15,58. Setelah mengamati nilai rata-rata dan simpangan baku kelas sampel, penulis menyimpulkan bahwa nilai rata-rata kelas eksperimen lebih tinggi dibandingkan dengan kelas kontrol. Untuk kejelasan dalam melihat perbandingan nilai yang terjadi secara sistematis, penulis menggunakan nilai rata-rata dan simpangan baku di kelas sampel untuk tahap pengujian hipotesis. Kemampuan berpikir kritis siswa yang diajarkan dengan menggunakan model pembelajaran Contextual Teaching and Learning lebih tinggi dibandingkan kemampuan berpikir kritis siswa yang diajarkan dengan menggunakan model 


\section{$\pi$ (Phi)}

pembelajaran langsung.

\section{DAFTAR PUSTAKA}

Arifin, Zaenal. 2009. Evaluasi Pembelajaran. Bandung: PT. Remaja Rosdakarya.

Arikunto, Suharsimi. 2010. Prosedur Penelitian. Jakarta: Rineka Cipta. .2013.Dasar-Dasar Evaluasi Pendidikan. Jakarta: Bumi Aksara.

Aqib, Zainal. 2014. Mode-Model, Media, dan Strategi Pembelajaran Kontekstual (Inovatif). Bandung: Tyama Widya.

Aunurrahman. 2014. Belajar dan Pembelajaran. Bandung: Alfabeta. Fisher, Alec. 2008. Berpikir Kritis. Jakarta: Erlangga.

Letari, Karunia Eka, dan Yudhanegara, Mokhammad Ridwan. 2015. Penelitian Pendidikan Matematika. Bandung: Refika Aditama.

Riduwan. 2013. Belajar Mudah Penelitian. Bandung: Alfabeta. Sagala, Syaiful. 2013. Konsep dan Makna Pembelajaran. Bandung: Alfabeta.

Shoimin, Aris. 2014. 68 Model Pembelajaran Inovatif dalam Kurikulum 2013. Yogyakarta: ArRuzz Media.

Sudjana. 2009. Metode Statistika. Bandung: Transito.

Sugiyono. 2013. Metode Penelitian Kuantitatif Kualitatif dan $R \& D$. Bandung: Alfabeta.

2015. Metode Penelitian Pendidikan. Bandung: Alfabeta. Supardi. 2013. Aplikasi Statistika dalam Penelitian. Jakarta Selatan: Change Publication.

Suprijono, Agus. 2011. Cooperative Learning Teori dan Aplikasi PAIKEM. Yogyakarta: Pustaka Belajar.

Susanto, Ahmad. 2014. Teori Belajar dan
Pembelajaran di Sekolah Dasar. Jakarta: Kencana.

Suyadi. 2013. Strategi Pembelajaran Pendidikan Karakter. Bandung: PT. Remaja Rosdakarya.

Trianto. 2012. Mendesain Model Pembelajaran Inovatif-Progresif. Jakarta: Kencana.

Wahab, Rohmalina. 2015. Psikologi Belajar. Jakarta: PT. Raja Grafindo Persada. 